\title{
Histidine-Rich Glycoprotein
}

National Cancer Institute

\section{Source}

National Cancer Institute. Histidine-Rich Glycoprotein. NCI Thesaurus. Code C88169.

Histidine-rich glycoprotein ( $525 \mathrm{aa}, \sim 60 \mathrm{kDa}$ ) is encoded by the human HRG gene. This protein may be involved in both ion binding and thrombosis. 